\title{
CHARACTERIZATION OF THE RHIZOPHORA PARTICLEBOARD AS A TISSUE-EQUIVALENT PHANTOM MATERIAL BONDED WITH BIO-BASED ADHESIVE
}

\author{
Ehsan Taghizadeh Tousi ${ }^{1, `}$, Rokiah Hashim², Sabar Bauk ${ }^{3}$, Mohamad Suhaimi Jaafar ${ }^{\text {, }}$ \\ Ali Mohammad Hamdan Abuarra ${ }^{1}$, Amer Mahmoud Al-Jarrah ${ }^{1}$, Baker Ababneh ${ }^{1}$, \\ Afsaneh Taghizadeh Tousi ${ }^{4}$, Khalid Saleh Ali Aldroobi ${ }^{1}$
}

\begin{abstract}
In this study, some characteristics of Rhizophora spp. particleboards bonded with Serishoom (traditional animal-based adhesive) as a phantom material was investigated. The Rhizophora spp. particleboards were fabricated in two Serishoom adhesive treatment levels $(6 \%$ and $12 \%)$ with three Rhizophora spp. particle sizes $(\leq 149 \mu \mathrm{m}, 149 \mu \mathrm{m}-500 \mu \mathrm{m}$, and $500 \mu \mathrm{m}-1000 \mu \mathrm{m})$ at $1{\mathrm{~g} . \mathrm{cm}^{-3} \text { of }}^{-1}$ the target density. The internal bond strength and the dimensional stability of the Serishoom-bonded Rhizophora spp. particleboards were improved by using the smaller Rhizophora spp. particle size and the higher Serishoom adhesive treatment level. The effective atomic numbers of the Serishoom-bonded Rhizophora spp. particleboards were determineted to be 7,56 to 7,58 by an energy dispersive X-ray, which is in good agreement with those of water and breast tissue. In addition, the density distribution profiles of the fabricated Serishoom-bonded Rhizophora spp. particleboards were determined by the Kriging method with the use Surfer8 computer software, which indicated that there was good density homogeneity throughout the Serishoom-bonded Rhizophora spp. particleboards. The results showed a potential of the Serishoom-bonded Rhizophora spp. particleboard bonded with Serishoom to be used as a phantom material.
\end{abstract}

Keywords: Bio-adhesive, effective atomic number, particleboard, Rhizophora sp., Serishoo.

\section{INTRODUCTION}

The risks of radiation are always being considered particularly in medical applications. Therefore, a simulated system, which is called phantom, has been used for quality control (QC), quality assurance (QA), and radiation protection (Attix 2008, Khan 2010). The phantom materials should have approximately the same response against radiation with that of human tissue. The interactions of photons with matter depend to some matter properties such as its density and effective atomic number. The water and solid (such as polystyrene and Perspex) homogeneous phantoms have been widely used in medical radiation centers, although they are not always practical and suitable to be used as a phantom (Khan 2010). Furthermore, there is always an interest to use local, readily available, and cheap phantom material, such as wood. Wood (with similar density of water as a standard material phantom) has been considered as a phantom material for some unique properties such as renewable, biodegradable, low toxicity, readily available, cheap, and easy to use and prepare (Tousi et al. 2014b).

\footnotetext{
${ }^{1}$ School of Physics, Universiti Sains Malaysia, Penang, Malaysia.

${ }^{2}$ Division of Bioresource, Paper and Coatings Technology, School of Industrial Technology, Universiti Sains Malaysia, Penang, Malaysia.

${ }^{3}$ Physics Section, School of Distance Education, Universiti Sains Malaysia, Penang, Malaysia

${ }^{4}$ Chemistry Section, Faculty of Science, Islamic Azad University, Mashhad Branch, Mashhad, Iran.

^Corresponding author: ehsan.tousi@yahoo.com

Received: 22.01.2014 Accepted: 11.07.2014
} 
Rhizophora spp. is traditionally being used to produce charcoal and as building materials (Atheull et al. 2009, Abuarra et al. 2014). It is a significant genus of mangrove trees that grows in the salty littoral tropical and subtropical sedimentary habitats (Hogarth and Hogarth 2007). The Rhizophora has the various genuses, and Rhizophora spp. refers to all types of the Rhizophora trees. Since the proposition of the suitability of Rhizophora spp. wood as a phantom material in 1988 (Sudin et al. 1988), some researchers have been investigating its characteristics further (Bradley et al. 1991, Tajuddin et al. 1996, Munem 1999, Banjade et al. 2001, Shakhreet et al. 2009). Nevertheless, there are some limitations for the utilization of the raw wood as a phantom, such as, the uncontrollable uniformity of some significant characteristics such as moisture content and density throughout the raw wood phantom. Furthermore, the raw wood tends to grow mold, get slimy, cracks and warps all over the wood phantom with passing time (Marashdeh et al. 2011). In addition, the Rhizophora spp. tree trunk is typically $20 \mathrm{~cm}$ to $25 \mathrm{~cm}$ in diameter (Hogarth and Hogarth 2007) and is not suitable to be used as a standard phantom with a typical size of $30 \mathrm{~cm} \times 30 \mathrm{~cm} \times 30 \mathrm{~cm}$.

The woods can be used in two general forms: raw wood, and engineered wood-based panels such as particleboard. Rhizophora spp. particleboard phantom has been considered by some researchers as an alternative to the raw wood phantom. The particleboards can be classified into two general types: binderless, and with the use of a binder material.

In a binderless particleboard, the wood particles bind together with some treatment such as pressure and temperature, in the absence of an adhesive. Marashdeh et al. 2011 investigated the properties of Rhizophora spp. binderless particleboard (Marashdeh et al. 2011, Marashdeh et al. 2012). The results of the mass attenuation coefficients were found very close to water as the standard material phantom (Marashdeh et al. 2012). However, the low internal bond (IB) strength of the Rhizophora spp. binderless particleboard restricts the practical utilization in medical radiation centers (Marashdeh et al. 2011). This is due to the fact that the binderless Rhizophora spp. particles were easily disintegrated by water in a short time. Thus, the dimensions of Rhizophora spp. binderless particleboards were not stable in the determination of water absorption (WA) and thickness swelling (TS).

The use of an adhesive as the binder in the Rhizophora spp. particleboard had also been considered. The adhesives can be classified into two main groups: synthetic and bio-based wood adhesives. The synthetic adhesives included urea formaldehyde (UF), phenol formaldehyde (PF) and phenol resorcinol formaldehyde (PRF), as the most widely used adhesives in the wood industry (Chew et al. 1991, MacDonald 2013), were used to fabricate Rhizophora spp. particleboards (Surani 2008, Ngu 2009). The mass attenuation coefficients of the Rhizophora spp. particleboard with UF, PF, and PRF synthetic wood adhesives were significantly far from those of breast tissue and water at $59,5 \mathrm{keV}$ photon energy. Moreover, thermal resistance of the formaldehyde is very low, that causes the emission of formaldehyde fume with passing time from formaldehyde-based wood adhesives (Hashim et al. 2011). The International Agency for Research on Cancer (IARC) has recognized formaldehyde as a carcinogenic substance (Bosetti et al. 2008). Therefore, formaldehyde-based wood adhesives can potentially be harmful for environmental and human (Hashim et al. 2009, Moubarik et al. 2010).

Natural adhesives have been used since the ancient civilizations such as in Iran, China, and Egypt (Bianchini and Meli 2002, Liu and Li 2002). There is always a concern about famine food in the world about the widely increasing utilization of bio-based materials in the fuel and industries. In this study, a type of animal-based adhesive was used to fabricate the Rhizophora spp. particleboards with $1 \mathrm{~g} . \mathrm{cm}^{-3}$ target density. This animal-based adhesive has been traditionally used and named Serishoom in Iran (Tousi et al. 2014c). Serishoom has been made from the inedible connective tissues (such as cartilage and bone) of domesticated ungulate animals (especially cow and goat) by prolonged boiling process. The dried Serishoom consists $85,7 \%$ crude protein, 13,7\% ash (mineral materials), and less than $1 \%$ total of the fat, fiber, and carbohydrate (Tousi et al. 2014c). Therefore, Serishoom can be classified as a protein-based adhesive. The viscosity of the Serishoom was about $6-25 \mathrm{mPa}$.s, which was in the 
viscosity range of the widely used synthetic adhesives in wood industry such as urea-formaldehyde (UF) and phenol-formaldehyde (PF) (Tousi et al. 2014a). Also, the viscosity of less than $50 \mathrm{mPa}$.s makes easier handling of the Serishoom.

In this study, Rhizophora spp. particleboards were fabricated using three Rhizophora spp. particle sizes $(\leq 149 \mu \mathrm{m}, 149 \mu \mathrm{m}-500 \mu \mathrm{m}$, and $500 \mu \mathrm{m}-1000 \mu \mathrm{m})$, and two Serishoom adhesive treatment levels (6\% and 12\%). The internal bond (IB) strength, water absorption (WA), and thickness swelling (TS) were evaluated as the mechanical and physical properties of the fabricated Rhizophora spp. particleboards. Also, the elemental composition and the effective atomic numbers of the Serishoom adhesive and the fabricated Rhizophora spp. particleboards were investigated with an energy dispersive X-ray (EDX). In addition, the density distribution profiles of the fabricated Rhizophora spp. particleboards were determined by the Kriging method with the use Surfer 8 computer software.

\section{MATERIALS AND METHODS}

\section{Preparation of Samples}

Rhizophora ssp. tree trunks, which were directly collected from the mangrove forestry office in Kuala Sepetang, Perak, Malaysia, were peeled and sawn into planks with approximately same thickness by a Formahero FH-600 BS saw. Then, the wood planks were repeatedly passed through an auto planer (Holy Tek HP 20) for shaving. The shavings were air dried and later ground to produce very small particles by a Tai-Yi Retch grinder. Finally, the Rhizophora spp. particles were screened by a horizontal screening machine to three different Rhizophora spp. particle sizes: $\leq 149 \mu \mathrm{m}, 149-500 \mu \mathrm{m}$, and $500-1000 \mu \mathrm{m}$.

The Serishoom was directly purchased from the traditional adhesive market in Mashhad, Razavi Khorasan Province, Iran. The Serishoom was ground and screened in sieves of $149 \mu \mathrm{m}-500 \mu \mathrm{m}$ particle size. The density of a water-equivalent phantom should be $1 \mathrm{~g} . \mathrm{cm}^{-3}$, so the target density of the fabricated particleboards was set at $1 \mathrm{~g} . \mathrm{cm}^{-3}$. The moisture content (MC) of the Serishoom and Rhizophora spp. particles were measured based on the Japanese Industrial Standard (JIS 2003) by using a Radwag MAC $50 / 1$ digital moisture analyzer. The MC is affected by some properties in the surrounding area such as humidity and temperature. Therefore, $\mathrm{MC}$ was measured before each step. The MC values of the Rhizophora spp. and Serishoom particles were typically determined to be 6-8\% and 4-6\%, respectively. Serishoom makes the stronger binding with additional water similar to other bio-based adhesive powder. The Rhizophora spp. particleboards bonded with Serishoom were fabricated with $10 \%$ to $40 \%$ of the amount of the additional water. The binders were easily fractured in the fabricated Rhizophora spp. particleboard with low percentage of the additional water. In other hand, the cleft surface was appeared in a high percentage of added water. As well as, with more additional water longer time is needed to remove moisture from the particleboard in the fabrication process, which causes the fabricated particleboard to be burnt. The $20 \%$ water in general (including the moisture contents of wood and glue particles) was used for stronger bonding in particleboard fabrication. The calculation for the particleboard fabrication is shown in Equation 1 (Tousi et al. 2014b):

$$
\begin{aligned}
& \rho=\frac{M}{V} ; \rho_{t}=1 g . \mathrm{cm}^{-3} \\
& M_{w}=(\% W) \times \rho V\left(1+\% M C_{w}\right) ; M_{\text {Seri }}=(\% \text { Seri }) \times \rho V\left(1+\% M C_{\text {Seri }}\right) \\
& M_{\text {water }}=(20 \%) \times \rho V-\left[\left(M_{w} \times \% M C_{w}\right)+\left(M_{\text {Seri }} \times \% M C_{\text {Seri }}\right)\right]
\end{aligned}
$$


where $\rho, \rho_{t} M$, and $V$ are the density, target density, mass, and volume of the fabricated particleboard, respectively. $M_{w} \% W$ and $\% M C_{w}$ are the mass, weight percentage, and moisture content of Rhizophora spp. wood particles, respectively. In addition, $M_{\text {Seri }} \%$ Seri and $\% M C_{\text {Seri }}$ are the mass, weight percentage, and moisture content of the Serishoom adhesive, respectively. $M_{\text {water }}$ is the mass of the additional water needed. The Rhizophora spp. particleboards bonded with Serishoom were fabricated in $21 \mathrm{~cm} \times 21 \mathrm{~cm}$ $\times 0,65 \mathrm{~cm}$ board size, approximately. In total 18 particleboards were fabricated, three particleboards for each of the 6 types. Table 1 shows the measured density of the Rhizophora spp. particleboard samples with three Rhizophora spp. particle sizes bonded with Serishoom at two adhesive treatment levels.

Table 1. Samples of the Rhizophora spp. particleboards with three Rhizophora spp. particle size, bonded with two weight percentages of the Serishoom adhesive.

\begin{tabular}{lllllll}
\hline Sample & Seri. & Rhiz.P.S. & \multicolumn{4}{c}{ Density $\left(\mathrm{g} . \mathrm{cm}^{-3}\right)$} \\
\cline { 4 - 7 } & $\%$ & $\mu \mathrm{m}$ & Max & Min & Avr. & St.Dv. \\
\hline A & 6 & $500-1000$ & 1,02 & 0,98 & 1,01 & 0,05 \\
B & 12 & $500-1000$ & 1,05 & 0,94 & 1,01 & 0,01 \\
C & 6 & $149-500$ & 1,01 & 0,99 & 1,01 & 0,01 \\
D & 12 & $149-500$ & 1,09 & 0,99 & 1,06 & 0,01 \\
E & 6 & $<149$ & 1,08 & 0,96 & 1,03 & 0,02 \\
F & 12 & $<149$ & 1,08 & 0,91 & 1,01 & 0,01 \\
\hline
\end{tabular}

Seri. \%: \% Weight Serishoom; St.Dv.: Standard Deviation

Rhiz. P.S.: Particle Size Rhizophora spp.; Avr.: Average

The fabrication process included two parts. The first part was cold pressing for about 15 min at $20 \mathrm{MPa}$ pressure. The second part was hot pressing that included four sections: (1) $10 \mathrm{MPa}$ pressure for $10 \mathrm{~min}$ in the rising temperature from $29{ }^{\circ} \mathrm{C}$ (room temperature) to $100{ }^{\circ} \mathrm{C}$; (2) $13 \mathrm{MPa}$ pressure for $10 \mathrm{~min}$ in the increasing temperature from $100{ }^{\circ} \mathrm{C}$ to $150{ }^{\circ} \mathrm{C}$; (3) $16 \mathrm{MPa}$ pressure for $10 \mathrm{~min}$ in enhancing temperature from $150{ }^{\circ} \mathrm{C}$ to $200{ }^{\circ} \mathrm{C}$. (4) $20 \mathrm{MPa}$ pressure for $5 \mathrm{~min}$ in the fixed temperature of the adhesive melting point. The particleboards were intermittently put under the pressure to gradually remove the water steam from the particleboard in order to avoid cracks on the fabricated particleboards.

\section{Internal Bond (IB) strength}

The fabricated Serishoom-bonded Rhizophora spp. particleboards, were cut into $5 \mathrm{~cm} \times 5 \mathrm{~cm}$ of samples to evaluate the internal bond (IB) strength based on the Japanese Industrial Standard for particleboard (JIS 2003). The samples were stuck to the aluminum IB moulds in $5 \mathrm{~cm} \times 5 \mathrm{~cm}$ surface size (sample and aluminum IB moulds have to be in the same sizes) from both sides by a hot-melt glue. The IB strength values were evaluated five times for each sample type. An UTM-5582: Instron Testing System (USA) with a load cell capacity of $1000 \mathrm{~kg}$ was used to determine the IB strength of the fabricated Rhizophora spp. particleboards bonded with Serishoom. The samples were pulled apart from both sides until the appearance of the fracture, which have to occur in the middle of the sample. The IB tester system gave a curve for each sample that showed the maximum load at the fracture time $\left(\mathrm{P}_{\max }\right.$. The IB strength value is calculated by Equation 2:

$$
\mathrm{IB}(\mathrm{MPa})=\mathrm{P}_{\max } /(\text { Area of the board sample surface })
$$




\section{Water Absorption (WA) and Thickness Swelling (TS)}

The practical utilization of the fabricated Serishoom-bonded Rhizophora spp. particleboard can be significantly affected by its dimensional stability, which can be evaluated by the WA and TS analyses. The fabricated Serishoom-bonded Rhizophora spp. particleboards were cut into $3 \mathrm{~cm} \times 3 \mathrm{~cm}$ board samples. The WA and TS of 6 samples from each of the 6 different types of fabricated particleboards were measured. According to the Japanese Industrial Standard for particleboards (JIS, 2003), the samples were immersed in distilled water at room temperature for 24 hours (Sahin and Arslan 2011). The thickness and the weight of the samples were measured in before immersion in water and after 30 min, 1, 2, 4, 6, 9, 12, 15, and $24 \mathrm{hr}$ of the immersion time. The WA and TS were calculated by Equations 3 and 4, respectively (JIS 2003):

$$
\begin{aligned}
& W A \%=\left(\frac{W-W_{0}}{W_{0}}\right) \times 100 \\
& T S \%=\left(\frac{T-T_{0}}{T_{0}}\right) \times 100
\end{aligned}
$$

where $W_{0}$ and $T_{0}$ are the initial weight and thickness of the samples, respectively. Also, $W$ and $T$ refer to the weight and thickness of the samples after $24 \mathrm{~h}$ of immersion time, respectively.

\section{Density Distribution}

The density distributions of the fabricated Rhizophora spp. particleboards bonded with the Serishoom adhesive were determined by the Kriging method with the use Surfer 8 computer software. The "Optimal prediction" is the literal meaning of the kriging (Journel and Huijbregts, 2003). The Kriging method derives the required parameter values at an unobserved location with random real measured data. The Rhizophora spp. particleboards bonded with Serishoom were fabricated in $21 \mathrm{~cm} \times 21 \mathrm{~cm} \times 0,65 \mathrm{~cm}$. The edges of fabricated particleboards were cut about $0,5 \mathrm{~cm}$ by a Formahero FH-600 BS saw. Then, 100 board samples of $2 \mathrm{~cm} \times 2 \mathrm{~cm}$ size were obtained from each fabricated Serishoom-bonded Rhizophora spp. particleboard by cutting. The density of each board sample was measured with an MD-200S, Alfa Mirage (Japan) electronic densimeter in $\mathrm{g} / \mathrm{cm}^{3}$ with $0,001 \mathrm{~g} . \mathrm{cm}^{-3}$ accuracy. As well as, the dimensions of the cut board samples were measured by using a digital vernier callipers in $\mathrm{cm}$ with $0,001 \mathrm{~cm}$ accuracy. Surfer 8 computer software is widely used to simulate a grid-based map from relation of 3 parameters (XYZ file) to find the equivalence points based on random real data XYZ input file (Golden-Software 2002). The locations coordinate of the middle point of each board samples were loaded as $X$ and $Y$ files (based on the measured dimensions). $\mathrm{Z}$ was the measured density of each board sample.

\section{Evaluation of the elemental composition and the effective atomic number}

The photoelectric effect, which is one of the most significant interaction of photons with matter especially in the low-energy photon range such as in a mammography technique, is actively affected by the atomic number $(Z)$ of the element or the effective atomic number $\left(Z_{e f f}\right)$ of the composite materials (Gunderson and Tepper 2007, Attix 2008, Olarinoye 2011). Hence, the response of two materials with the same effective atomic number could be significantly closer together under the radiation especially in the low-energy range. The effective atomic number of the new phantom material has to be in good agreement with those of human tissue and water as the standard phantom material. The Zeff is calculated by Equation 5 (Tsai and Cho 1976, Duvauchelle et al. 1999, Olarinoye 2011):

$$
Z_{\text {eff }}=\left(\sum_{i=1}^{N}\left(\alpha_{i} Z_{i}^{m}\right)\right)^{\left(\frac{1}{m}\right)}
$$


where $\alpha_{i}$ and $Z_{i}$ are the electronic fraction and atomic number of the $i^{\text {th }}$ element in the composite, respectively. Also, $\mathrm{m}$ is an experimental coefficient, which is 3,4 for the biological substance such as tissue and wood (Tsai and Cho 1976, Duvauchelle et al. 1999). As well as, using Equation 6 gives the electronic fraction of the $i^{\text {th }}$ element ( $\alpha i$ ) (Duvauchelle et al. 1999, Olarinoye 2011):

$$
\alpha_{i}=\frac{w_{i}\left(\frac{Z_{i}}{A_{i}}\right)}{\sum w_{i}\left(\frac{Z_{i}}{A_{i}}\right)}
$$

where, $w_{i}, Z_{i^{\prime}}$ and $A_{i}$ are fractional weight, atomic number, and atomic number of the $i^{\text {th }}$ element, respectively. An energy dispersive X-ray (EDX) (model: Oxford X-ray Act) was used to evaluate the elemental compositions of the Serishoom adhesive and the fabricated Rhizophora spp. particleboards with three Rhizophora spp. particle sizes bonded with Serishoom in two treatment levels in three replicates for the different samples. All elements of the Periodic Table can be detected by EDX technique, except hydrogen and helium (Neagle and Randell 1990).

\section{RESULTS AND DISCUSSION}

\section{Characterization of the internal bond strength}

Figure 1 shows the average of the IB strength values of Rhizophora spp. particleboard bonded with Serishoom. The minimum requirement for the IB strength value for types 8,13 , and 18 particleboards are $0,15,0,20$, and $0,30 \mathrm{MPa}$ respectively by the Japanese Industrial Standard for particleboards JIS, A-5908 (JIS 2003).

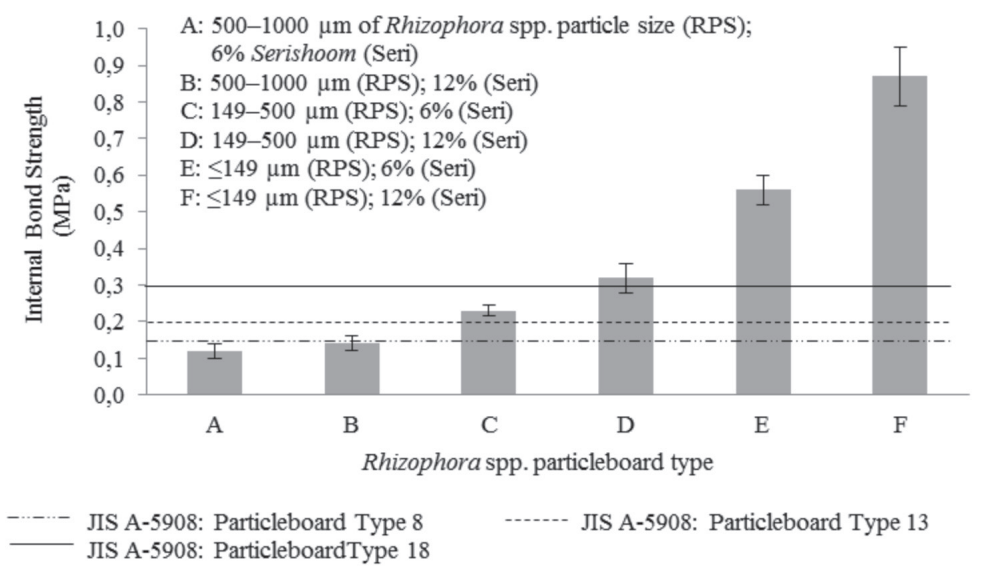

Figure 1. Internal Bond (IB) strength values of the fabricated Serishoom-bonded Rhizophora spp. particleboards. 
The IB strengths of Samples A and B with the biggest Rhizophora spp. particles $(500-1000 \mu \mathrm{m})$ could not meet the required minimum IB strength values of the Japanese Industrial Standard for particleboards JIS, A-5908 (JIS, 2003). The IB value of Sample C was found higher than the minimum IB strength values of types 8 and 13 particleboards by the Japanese Industrial Standard for particleboards JIS, A-5908. Samples D, E, and F covered the minimum IB strength values of types 8, 13, and 18 particleboards by the Japanese Industrial Standard for particleboards JIS, A-5908. Thus, the IB strength of the fabricated Serishoom-bonded Rhizophora spp. particleboard bonded with Serishoom is affected by the Rhizophora spp. particle size and adhesive treatment level.

Geometrically, the Rhizophora spp. particles with smaller size have less void space and more connecting surface areas to hold together. The increase in the connecting surface area causes the increase in the IB strength value (Hashim et al. 2010). Hence, the IB strength value of the fabricated Rhizophora spp. particleboard increased with the smaller Rhizophora spp. particle sizes, as in the studies of the Rhizophora spp. (Marashdeh et al. 2011), oil palm (Hashim et al. 2010), aspen bark (Yemele et al. 2008), and rice husk (Osarenmwinda and Nwachukwu 2007) binderless particleboards. The IB strength value of the fabricated Serishoom-bonded Rhizophora spp. particleboard also increased with higher Serishoom adhesive treatment level due to the presence of more binding Serishoom adhesive particles.

\section{Evaluation of the water absorption and thickness swelling}

Figures 2 and 3 show the WA and TS values of the fabricated Rhizophora spp. particleborads bonded with Serishoom adhesive.

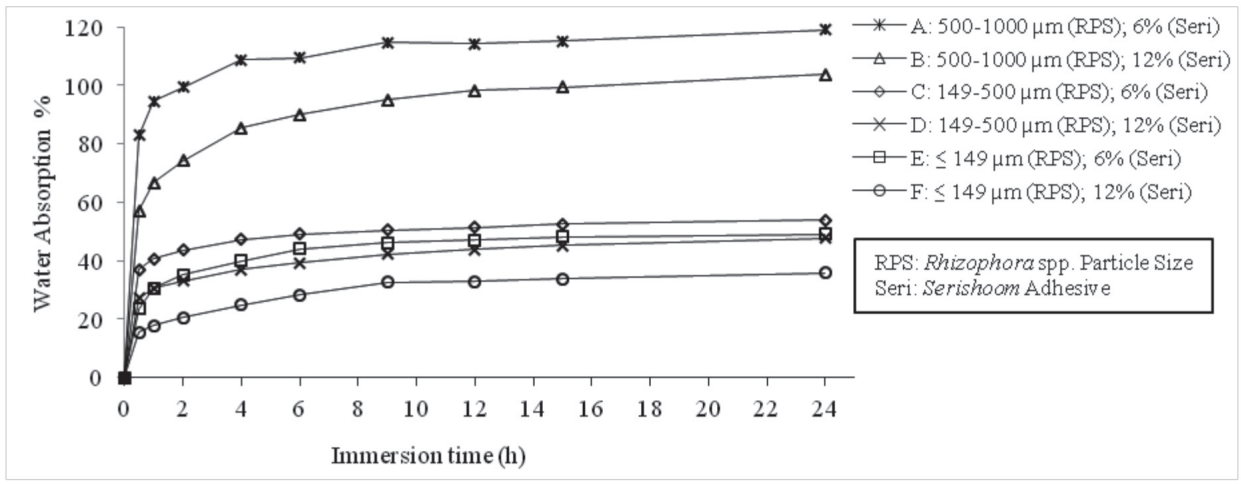

Figure 2. The percentage of water absorptions of the fabricated Serishoom-bonded Rhizophora spp. particleboards. 


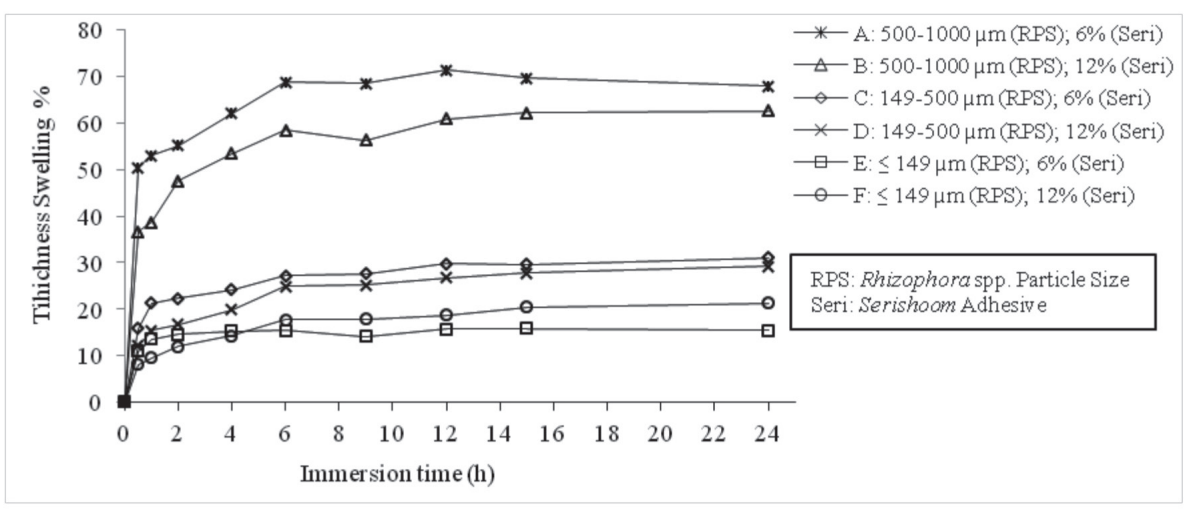

Figure 3. The percentage of thickness swelling of the fabricated Serishoom-bonded Rhizophora spp. particleboards.

The WA and TS values of all samples quickly increased in the first 30 min after the start of immersion process. The WA and TS values of the fabricated Rhizophora spp. particleboards slowly increased after the first hour of the immersion time. The WA and TS values of the fabricated particleboard represent the dimensional stability. The lower WA and TS values indicate the more dimensional stability of the particleboard (Nadhari et al. 2013, Tousi et al. 2014b). Figure 4 shows the WA and TS values of the fabricated Rhizophora spp. particleboards after $24 \mathrm{~h}$ of the immersion time.

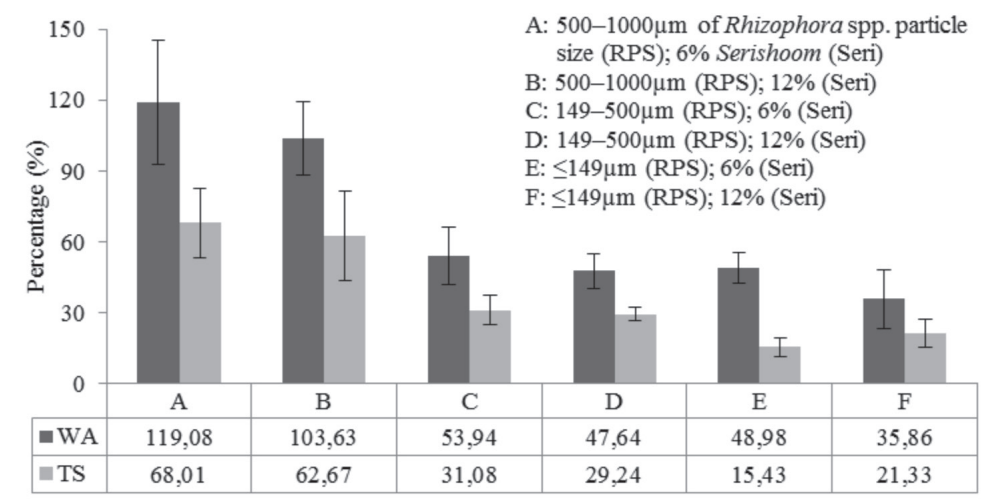

Figure 4. The WA and TS values of the fabricated Serishoom-bonded Rhizophora spp. particleboards after 24 hours immersion time.

According to figure 4, the absorption of water is significantly affected by the types of samples. The WA and TS values of the fabricated Rhizophora spp. particleboards at the same adhesive treatment level (6\%: Sample A, C, and E; 12\%: Samples B, D, and F) increased with the increase of Rhizophora spp. particle size. The smaller dimension of the Rhizophora spp. particles makes the smaller void space. Therefore, the connecting area increases with smaller Rhizophora spp. particle. The dimensional stability increases with more connecting area. 
The WA and TS values of the fabricated Rhizophora spp. particleboard decreased with the increase of Serishoom adhesive treatment level for the same Rhizophora spp. particle size $(500 \mu \mathrm{m}-1000 \mu \mathrm{m}$ : Samples A and B; $149 \mu \mathrm{m}-500 \mu \mathrm{m}$ : Samples C and D; $\leq 149 \mu \mathrm{m}$ : Samples E and F), except the TS value at $\leq 149 \mu \mathrm{m}$ of the Rhizophora spp. particle size (Samples E and F). The more adhesive particles cause to make the stronger binding in throughout of the fabricated Rhizophora spp. particleboard. The Serishoom particle size was $149 \mu \mathrm{m}-500 \mu \mathrm{m}$ for all samples. Therefore the hydrophilic bigger Serishoom adhesive particles absorbed more water in the fabricated Rhizophora spp. particleboard with smallest Rhizophora spp. particle ( $\leq 149 \mu \mathrm{m}$ : Samples E and F). In general, the dimensional stability of the fabricated Rhizophora spp. particleboard increased with higher Serishoom adhesive treatment level.

\section{Density distribution profile}

The contour lines of equal density of the fabricated Rhizophora spp. particleboards bonded with Serishoom adhesive were simulated with the Kriging method by Surfer 8 computer code, which are shown in figure 5. The lowest density value was related to the edge areas of the fabricated Rhizophora spp. particleboards, where the moisture in the particleboard escaped as steam from the particleboards during

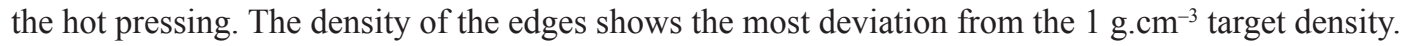

Table 2 shows the maximum, minimum, mean, and the percentage difference from target density (1 g.cm-3) for the fabricated Rhizophora spp. particleboards bonded with Serishoom. The difference between the density values of the fabricated Rhizophora spp. particleboards and target material (water) were found to be less than $5 \%$.
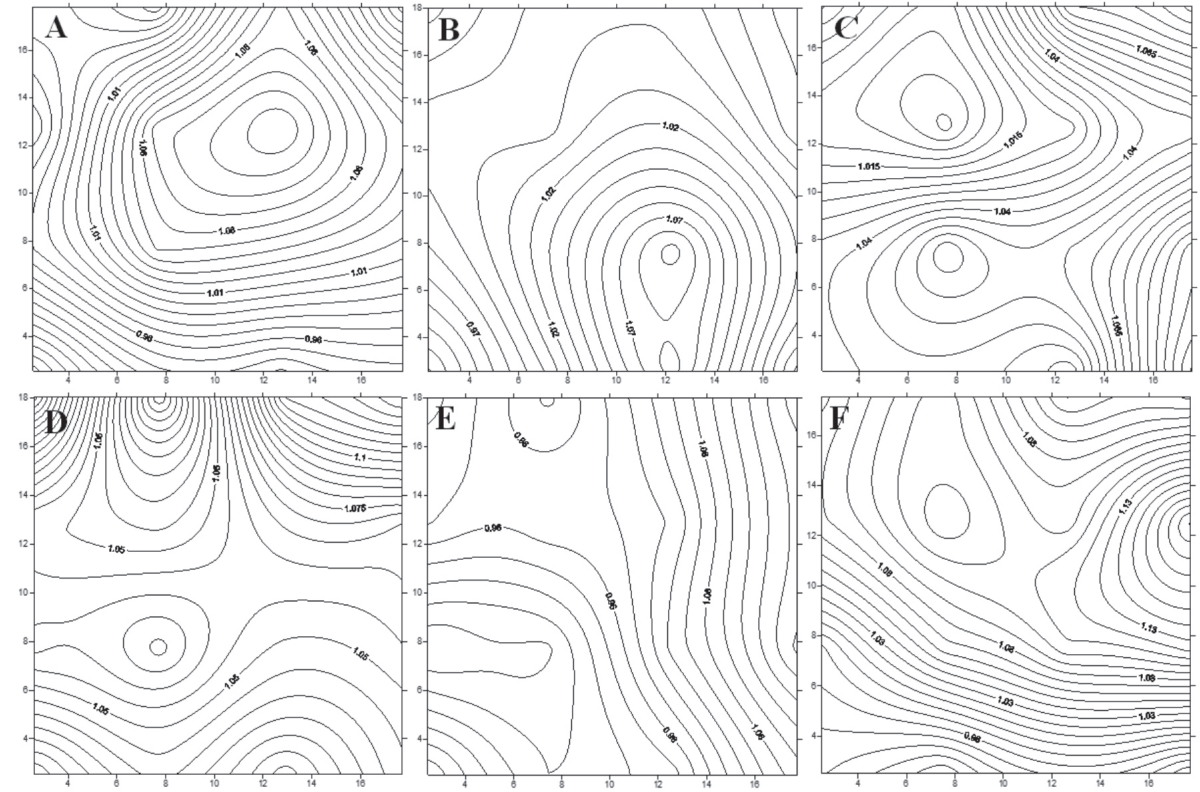

Figure 5. The simulated contour lines of equal density of Serishoom-bonded Rhizophora spp. particleboards by using the Surfer 8 computer software. 
Table 2. The results of the simulated density values of the fabricated Serishoom-bonded Rhizophora spp. particleboard using the Kriging method by Surfer8 computer software.

\begin{tabular}{llllcl}
\hline Sample & \multicolumn{3}{c}{ Density $\left(\mathrm{g} . c m^{-3}\right)$} & Difference with & St. \\
\cline { 2 - 4 } & Min & Max & Mean & target density (\%) & Dv. \\
\hline A & 0,90 & 1,10 & 1,01 & 1,20 & 0,06 \\
B & 0,95 & 1,09 & 1,01 & 1,16 & 0,03 \\
C & 1,00 & 1,08 & 1,02 & 2,08 & 0,03 \\
D & 1,00 & 1,14 & 1,05 & 4,06 & 0,03 \\
E & 0,92 & 1,06 & 0,98 & 2,20 & 0,04 \\
F & 0,92 & 1,19 & 1,04 & 4,20 & 0,08 \\
\hline \multicolumn{5}{c}{ St.Dv.: Standard Deviation }
\end{tabular}

Therefore, all of the fabricated Rhizophora spp. particleboards were found close to the target density. Sample F (with the smallest Rhizophora spp. particle size and the higher Serishoom adhesive treatment level) has the biggest standard deviation value, which indicates the lowest density homogeneity of the Serishoom-bonded Rhizophora spp. particleboards. Also, the density of the fabricated Rhizophora spp. particleboard was further from the target density by the increased Serishoom treatment level with the same Rhizophora spp. particle size, exept the Serishoom-Rhizophora spp. particleboards with the biggest Rhuzophora paricles (Samples A and B). As well as, the density of the fabricated Rhizophora spp. particleboard was closer than target density by the increased Rhizophora spp. particle size for the same Serishoom treatment level.

\section{Evaluation of the effective atomic number}

Table 3 shows the elemental components and the measured effective atomic number of Rhizophora spp. wood (Sudin, 1993), water (AAPM-21 1983, AAPM-25 1988, Qi et al. 2010), young-age breast tissue (25\% fat and $75 \%$ muscle) (Shakhreet et al. 2009), Serishoom adhesive, and fabricated Serishoom-bonded Rhizophora spp. particleboards. The $\mathrm{Z}_{\text {eff }}$ of the Serishoom adhesive and the Rhizophora spp. wood was calculated 8,48 and 7,31, respectively. Therefore, $Z_{\text {eff }}$ value of the Rhizophora spp. wood was found very close to those of water and young-age breast tissue, with $1,48 \%$ and $0,27 \%$ of the percentage difference, respectively. Nevertheless, the $Z_{\text {eff }}$ of Serishoom adhesive was not in good agreement with those of water and young-age breast tissue. Therefore, the Serishoom can not be used alone as a phantom material.

Table 3. The elemental components and the calculated effective atomic number of water, breast tissue (young-age), Rhizophora spp. wood, Serishoom bio-adhesive, and fabricated Serishoom-

bonded Rhizophora spp. particleboards.

\begin{tabular}{|c|c|c|c|c|c|c|c|c|c|c|c|c|}
\hline \multirow{2}{*}{ Sample } & \multicolumn{11}{|c|}{ Elemental Components } & \multirow{2}{*}{$Z_{\text {eff }}$} \\
\hline & $\mathrm{H}$ & $\mathrm{C}$ & $\mathrm{N}$ & $\mathrm{O}$ & $\mathrm{Na}$ & $\mathrm{Mg}$ & $\mathrm{P}$ & $\mathrm{S}$ & $\mathrm{Cl}$ & $\mathrm{K}$ & $\mathrm{Ca}$ & \\
\hline Water $^{\mathrm{a}}$ & 11,11 & & & 88,89 & & & & & & & & $7,42^{\mathrm{c}}$ \\
\hline Breast $1^{\mathrm{b}}$ & 10,70 & 28,30 & 2,63 & 57,60 & 0,06 & 0,02 & 0,15 & 0,38 & 0,06 & 0,23 & 0,01 & 7,29 \\
\hline Rhiz. $^{c}$ & 5,41 & 40,20 & 0,03 & 54,40 & & & & & & & & 7,31 \\
\hline Seri. & & 40,80 & 26,20 & 26,50 & 2,21 & 0,14 & 0,44 & & 2,96 & & 0,65 & 8,48 \\
\hline A & & 27,25 & & 72,75 & & & & & & & & 7,57 \\
\hline B & & 27,05 & & 72,95 & & & & & & & & 7,58 \\
\hline $\mathrm{C}$ & & 27,32 & & 72,68 & & & & & & & & 7,57 \\
\hline D & & 27,26 & & 72,74 & & & & & & & & 7,57 \\
\hline $\mathrm{E}$ & & 27,33 & & 72,67 & & & & & & & & 7,57 \\
\hline $\mathrm{F}$ & & 28,15 & & 71,85 & & & & & & & & 7,56 \\
\hline
\end{tabular}


Carbon and oxygen were only detected as the component elements in all fabricated Rhizophora spp. particleboards bonded with Serishoom adhesive. The $\mathrm{Z}_{\text {eff }}$ values of the fabricated Rhizophora spp. particleboards were calculated to be in the range of 7,56 to 7,58. Therefore, the percentage errors of the $\mathrm{Z}_{\text {eff }}$ values of the fabricated Rhizophora spp. particleboards with young age breast tissue were found to be 3,70\% to 3,98\%. As well as, the percentage of the difference between $\mathrm{Z}_{\text {eff }}$ of the fabricated Rhizophora spp. particleboards and that of water were $1,89 \%$ to $2,16 \%$. Therefore, the $Z_{\text {eff }}$ values of the fabricated Serishoom-bonded Rhizophora spp. particleboards were found very close to those of water and breast tissue, which indicates its potential to be used as a phantom material.

\section{CONCLUSIONS}

In this study, the characteristics of the fabricated Serishoom-bonded Rhizophora spp. particleboards in two adhesive treatment levels $(6 \%$ and $12 \%)$ and three Rhizophora spp. particle sizes $(\leq 149 \mu \mathrm{m}$, $149-500 \mu \mathrm{m}$, and $500-1000 \mu \mathrm{m})$ with $1 \mathrm{~g} . \mathrm{cm}^{-3}$ target density were investigated. Their internal bond (IB) strength, water absorption (WA), and thickness swelling (TS) were evaluated. The IB strength value increased with the smaller Rhizophora spp. particle size and higher Serishoom treatment level. Also, the WA value decreased with the reduced Rhizophora spp. particle size and increased Serishoom adhesive treatment level. Similarly, the TS value decreased with the smaller Rhizophora spp. particle size. The TS value, however, increased with the higher Serishoom adhesive treatment level for $\leq 149 \mu \mathrm{m}$ of the Rhizophora spp. particle size, which showed the hydrophilic property of the Serishoom adhesive. The effective atomic numbers $\left(\mathrm{Z}_{\text {eff }}\right)$ of the fabricated Serishoom-bonded Rhizophora spp. particleboards were found very close to those of water and young-breast tissue, which shows its potential as a phantom material. In addition, the density distribution profiles of the fabricated Rhizophora spp. particleboards (with $1{\mathrm{~g} . \mathrm{cm}^{-3}}^{-3}$ target density) were determined by the Kriging method with the use Surfer 8 computer software indicates the potential of the Serishoom-bonded Rhizophora spp. particleboard as a phantom material especially in diagnostic photon energy level.

\section{ACKNOWLEDGMENTS}

The authors are grateful Universiti Sains Malaysia for the financial support provided by the research grant No. 1001/PFIZIK/845019. As well as, our sincere appreciation goes to the staffs of University Sains Malaysia in Penang, Malaysia and Department of Forestry office in Kuala Sepetang, Perak, Malaysia, who helped us. Also, the authors would like to acknowledge Wan Noor Aidawati binti Wan Nadhari for her friendly helping. 


\section{REFERENCES}

AAPM-21. 1983. Protocol for the determination of absorbed dose from high-energy photon and electron beams: Task Group 21. Med Phys 10 (6): 741-771.

AAPM-25. 1988. Protocols for the radiation safety surveys of diagnostic radiological equipment: Task Group 25. American Association of Physicists in Medicine, American institute of Physics, New York.

Abuarra, A.; Hashim, R.; Bauk, S.; Kandaiya, S.; Tousi, E.T. 2014. Fabrication and characterization of gum Arabic bonded Rhizophora spp. particleboards. Mate Des 60: 108-115.

Atheull, A.N.; Din, N.; Longonje, S.N.; Koedam, N.; Dahdouh-Guebas, F. 2009. Commercial activities and subsistence utilization of mangrove forests around the Wouri estuary and the Douala-Edea reserve (Cameroon). J Ethnobiol Ethnomed 5 (1): 35-49.

Attix, F.H. 2008. Introduction to radiological physics and radiation dosimetry. Wiley-VCH, New York.

Banjade, D.P.; Tajuddin, A.A.; Shukri, A. 2001. A study of Rhizophora spp. wood phantom for dosimetric purposes using high-energy photon and electron beams. Appl Radiat Isot 55 (3): 297-302.

Bianchini, C.; Meli, A. 2002. Alternating copolymerization of carbon monoxide and olefins by single-site metal catalysis. Coord Chem Rev 225 (1): 35-66.

Bosetti, C.; Mclaughlin, J.; Tarone, R.; Pira, E.; La Vecchia, C. 2008. Formaldehyde and cancer risk: a quantitative review of cohort studies through 2006. Ann Oncol 19 (1): 29-43.

Bradley, D.A.; Tajuddin, A.A.; Sudin, C.W.A.C.W.; Bauk, S. 1991. Photon attenuation studies on tropical hardwoods. Int J Rad Appl Instrum A: Appl Radiat Isot 42(8): 771-773.

Chew, L.; Wong, W.; Midon, M.S.; Matsumoto, T. 1991. A study on the properties of synthetic adhesives available in Peninsular Malaysia. J Trop For Sci 3 (3): 196-203.

Constantinou, C. 1982. Phantom materials for radiation dosimetry. I. Liquids and gels. Brit J Radiol 55: $217-224$.

Duvauchelle, P.; Peix, G.; Babot, D. 1999. Effective atomic number in the Rayleigh to Compton scattering ratio. Nucl Instrum Meth B 155(3): 221-228.

Golden-Software 2002. Surfer: User's Guide. Golden Software, Inc. Colorado.

Gunderson, L.L.; Tepper, J.E. 2007. Clinical radiation oncology. Saunders, Elsevier Inc. Philadelphia.

Hashim, R.; Nadhari, W.N.A.W.; Sulaiman, O.; Kawamura, F.; Hiziroglu, S.; Sato, M.; Sugimoto, T.; Seng, T.G.; Tanaka, R. 2011. Characterization of raw materials and manufactured binderless particleboard from oil palm biomass. Mater Des 32 (1): 246-254.

Hashim, R.; Saari, N.; Sulaiman, O.; Sugimoto, T.; Hiziroglu, S.; Sato, M.; Tanaka, R. 2010. Effect of particle geometry on the properties of binderless particleboard manufactured from oil palm trunk. Mater Des 31 (9): 4251-4257. 
Hashim, R.; Siti Hazneza, A.; Sulaiman, O.; Norli, I.; Hakimi, I.M.; Hasnah, M.J.; Salmiah, U. 2009. Extractable formaldehyde from waste medium density fibreboard. J Trop For Sci 21 (1): 25-33.

Hogarth, P.; Hogarth, P.J. 2007. The biology of mangroves and seagrasses. Oxford University Press, Oxford.

Japanese Standard Association. JIS. 2003. Particleboards. JIS A 5908. Japan.

Journel, A.G.; Huijbregts, C.J. 2003. Mining geostatistics. Blackburn Press, Caldwell, New Jersey.

Khan, F.M. 2010. The physics of radiation therapy. Lippincott Williams \& Wilkins, Philadelphia.

Liu, Y.; Li, K. 2002. Chemical modification of soy protein for wood adhesives. Macromol Rapid Commun 23 (13): 739-742.

Macdonald, N. 2013. Woodworking. Cengage Learning, New York.

Marashdeh, M.W.; Bauk, S.; Tajuddin, A.A.; Hashim, R. 2012. Measurement of mass attenuation coefficients of Rhizophora spp. binderless particleboards in the $16.59-25.26 \mathrm{keV}$ photon energy range and their density profile using x-ray computed tomography. Appl Radiat Isot 70(4): 656-662.

Marashdeh, M.W.; Hashim, R.; Tajuddin, A.A.; Bauk, S.; Sulaiman, O. 2011. Effect of particle size on the characterization of binderless particleboard made from Rhizophora spp. Mangrove wood for use as phantom material. BioResources 6 (4): 4028-4044.

Moubarik, A.; Allal, A.; Pizzi, A.; Charrier, F.; Charrier, B. 2010. Preparation and mechanical characterization of particleboard made from maritime pine and glued with bio-adhesives based on cornstarch and tannins. Maderas-Cienc Tecnol 12: 189-197.

Munem, E.M.E.A. 1999. Radiation dose distribution measurements around brachytherapy sources in water and Rhizophora spp. phantom. Master Thesis, Universiti Sains Malaysia, Penang, Malaysia.

Nadhari, W.N.A.W.; Hashim, R.; Sulaiman, O.; Sato, M.; Sugimoto, T.; Selamat, M.E. 2013. Utilization of Oil Palm Trunk Waste for Manufacturing of Binderless Particleboard: Optimization Study. BioResources 8 (2): 1675-1696.

Neagle, W.; Randell, D.R. 1990. Surface analysis techniques and applications. Royal Society of Chemistry, Cambridge.

Ngu, K.T. 2009. Fabrication of $1.0 \mathrm{~g} / \mathrm{cm}^{3}$ Rhizophora spp. particleboard and determination of their mass attenuation coefficient. Master Thesis, Universiti Sains Malaysia, Penang, Malaysia.

Olarinoye, I. 2011. Variation of Effective Atomic Numbers of some Thermoluminescence and Phantom Materials with Photon Energies. Res J Chem Sci 1 (2): 64-69.

Osarenmwinda, J.; Nwachukwu, J. 2007. Effect of particle size on some properties of rice husk particleboard. Adv Mater Res 18: 43-48.

Qi, Z.; Zambelli, J.; Bevins, N.; Chen, G.H. 2010. Quantitative imaging of electron density and effective atomic number using phase contrast CT. Phys Med Biol 55 (9): 2669-2677. 
Shakhreet, B.Z.; Bauk, S.; Tajuddin, A.A.; Shukri, A. 2009. Mass attenuation coefficients of natural Rhizophora spp. wood for X-rays in the $15.77-25.27 \mathrm{keV}$ range. Radiat Prot Dosim 135 (1): 47-53.

Sudin, C.W.A.C.W. 1993. Kayu tropika sebagai bahantara setaraan tisu untuk kajian dosimetri. Master Thesis, Universiti Sains Malaysia, Penang, Malaysia.

Sudin, C.W.A.C.W.; Tajuddin, A.A.; Bradley, D.A. 1988. Evaluation of tissue-equivalent media for dosimetric studies. In Proceeding of local seminar activities on radiation physics, biophysics and medical physics, Kuala Lumpur, Malaysia. pp. 71-80.

Surani, B.T. 2008. The suitability of PF, UF, and PRF resins in term of structure and attenuation properties to be used in Rhizophora Spp. particleboard phantom. Master Thesis, Universiti Sains Malaysia, Penang, Malaysia.

Tajuddin, A.A.; Sudin, C.W.A.C.W.; Bradley, D.A. 1996. Radiographic and scattering investigation on the suitability of Rhizophora spp. as tissue-equivalent medium for dosimetric study. Radiat Phys Chem 47 (5): 739-740.

Tousi, E.T.; Bauk, S.; Hashim, R.; Jaafar, M.S.; Abuarra, A.M.H.; Aldroobi, K.S.A.; Al-Jarrah, A.M. 2014a. Measurement of Mass Attenuation Coefficients of Eremurus-Rhizophora spp. Particleboards for X-ray in the $16.63-25.30 \mathrm{keV}$ Energy Range. Radiat. Phys Chem 103: 119-125.

Tousi, E.T.; Hashim, R.; Bauk, S.; Jaafar, M.S.; Al-Jarrah, A.M.; Kardani, H.; Abuarra, A.M.H.; Aldroobi, K.S.A. 2014b. Some properties of particleboards produced from Rhizophora spp. as a tissue-equivalent phantom material bonded with Eremurus spp. Measurement 54: 14-21.

Tousi, E.T.; Hashim, R.; Bauk, S.; Jaafar, M.S.; Al-Jarrah, A.M.; Kardani, H.; Abuarra, A.M.H.; Aldroobi, K.S.A. 2014c. A Study of the Properties of Animal-Based Wood Glue. Adv Mater Res 935: 133-137.

Tsai, C.M.; Cho, Z.H. 1976. Physics of contrast mechanism and averaging effect of linear attenuation coefficients in a computerized transverse axial tomography (CTAT) transmission scanner. Phys Med Biol 21 (4): 544-559.

Yemele, M.C.N.; Blanchet, P.; Cloutier, A.; Koubba, A. 2008. Effect of bark content and particle geometry on the physical and mechanical properties of particleboard made from black spruce and trembling aspen bark. Forest Prod J 58 (11): 48-56. 